\title{
PENGARUH LAMA PENUMBUHAN TITANIUM DIOKSIDA DIDOPING COPPER TERHADAP ENERGI GAP
}

\author{
Ade Usra Berli ${ }^{1}$, Dahyunir Dahlan ${ }^{1}$, Akrajas Ali Umar ${ }^{2}$ \\ ${ }^{1}$ Jurusan Fisika FMIPA Universitas Andalas, Limau Manis, Padang, 25163 \\ ${ }^{2}$ Institute of Microengineering and Nanoelectronics, Universiti Kebangsaan \\ Malaysia, 43600 UKM Bangi, Selangor, Malaysia \\ Email:adeusra@yahoo.co.id
}

\begin{abstract}
ABSTRAK
Deposisi lapisan $\mathrm{TiO}_{2}$ didoping $\mathrm{Cu}$ telah berhasil ditumbuhkan dengan menggunakan metoda Liquid Phase Deposition (LPD). Lapisan $\mathrm{TiO}_{2}-\mathrm{Cu}$ dibuat dengan menggunakan material Ammonium hexafluorotitanate $\left(\left(\mathrm{NH}_{4}\right)_{2} \mathrm{TiF}_{6}\right)$, Copper (II) Nitrate hydrate $\left(\mathrm{Cu}\left(\mathrm{NO}_{3}\right)_{2} \cdot \mathrm{xH}_{2} \mathrm{O}\right)$, dan Hexamethylen tetramine $\left(\mathrm{C}_{6} \mathrm{H}_{12} \mathrm{~N}_{4}\right)$. Dalam penelitian ini dilakukan variasi lama penumbuhan lapisan yaitu 3 jam, 5 jam, 7 jam dan 10 jam. Lapisan $\mathrm{TiO}_{2}-\mathrm{Cu}$ dikarakterisasi menggunakan Spektrometri Ultraviolet-Visible (UV-Vis) untuk menentukan energi gap melalui spektra difusi reflektansi. Hasil energi gap yang diperoleh pada lapisan $\mathrm{TiO}_{2}-\mathrm{Cu}$ dengan variasi lama penumbuhan yaitu antara 3,26-3,30 eV.

Kata kunci: Titanium dioksida $\left(\mathrm{TiO}_{2}\right)$, Liquid Phase Deposition (LPD) dan doping
\end{abstract}

\section{ABSTRACT}

Deposition of $\mathrm{TiO}_{2}$ doped $\mathrm{Cu}$ films have been successfully grown by using Liquid Phase Deposition (LPD) metod. $\mathrm{TiO}_{2}-\mathrm{Cu}$ films made by using Ammonium hexafluorotitanate $\left(\left(\mathrm{NH}_{4}\right)_{2} \mathrm{TiF}_{6}\right)$, Copper (II) Nitrate hydrate $\left(\mathrm{Cu}\left(\mathrm{NO}_{3}\right)_{2} \cdot \mathrm{xH}_{2} \mathrm{O}\right)$ and Hexamethylen tetramine $\left(\mathrm{C}_{6} \mathrm{H}_{12} \mathrm{~N}_{4}\right)$. In this research, the time variation of the growth films are 3 hours, 5 hours, 7 hours and 10 hours. $\mathrm{TiO}_{2}-\mathrm{Cu}$ films was characterized using Spectrometry Ultraviolet-Visible (UV-Vis) to determine the energy gap via diffusion reflectance spectra. The Values of energy gap $\mathrm{Cu}_{1} \mathrm{TiO}_{2}$ film with the time variation of growth films produce range 3,26-3,30 eV.

Keywords: (Titanium dioxide) $\mathrm{TiO}_{2}$, Liquid Phase Deposition (LPD) and doping

\section{PENDAHULUAN}

Titanium Dioksida $\left(\mathrm{TiO}_{2}\right)$, salah satu semikonduktor yang menjanjikan dan telah banyak diteliti karena fabrikasinya yang mudah dan murah. $\mathrm{TiO}_{2}$ telah banyak digunakan dalam berbagai aplikasi antara lain fotokatalis, sensor, dan sel surya (Saad, dkk., 2014). Pada aplikasi sel surya tersensitisasi pewarna (Dye Sensitized Solar Cell, DSSC) $\mathrm{TiO}_{2}$ telah banyak digunakan sebagai elektroda kerja yang berperan sebagai fotokatalis karena memiliki permukaan yang luas sehingga mampu menyerap molekul dye lebih banyak (Li, dkk., 2010). Banyaknya dye yang terserap pada $\mathrm{TiO}_{2}$ dapat meningkatkan jumlah aliran foton yang dihasilkan.

$\mathrm{TiO}_{2}$ murni memiliki celah pita energi (energi gap) yang lebar antara 3,2-3,8 eV yang menyebabkan daya serap terhadap cahaya berada di spektrum sinar ultra violet (Nurmawarti, dkk., 2009). Hal ini berpengaruh terhadap efisiensi dari DSSC. Untuk menurunkan energi gap maka diperlukan energi foton yang lebih rendah. Penurunan ini untuk mempermudah eksitasi elektron dari pita valensi ke pita konduksi. Penurunan energi gap dapat memperlebar spektrum penyerapan cahaya. Selain karena cukup besarnya energi gap yang dimiliki $\mathrm{TiO}_{2}$, adanya proses rekombinasi elektron-hole pada permukaan $\mathrm{TiO}_{2}$ masih cukup dominan juga menjadi faktor yang mempengaruhi efisiensi DSSC (Saehana, dkk,. 2010). 
Usaha untuk menurunkan energi gap dan mengurangi adanya rekombinasi elektron - hole dapat dilakukan penyisipan bahan pengotor (dopan) atau istilahnya doping ke dalam semikonduktor $\mathrm{TiO}_{2}$. Pendopingan dapat dilakukan dengan menggunakan beberapa logam transisi. Salah satu logam transisi yang digunakan untuk bahan doping pada lapisan $\mathrm{TiO}_{2}$ yaitu copper $(\mathrm{Cu})$ (Roose, dkk., 2015).

Beberapa metoda sudah pernah digunakan dalam penumbuhan lapisan $\mathrm{TiO}_{2}$ diantaranya yaitu Chemical Vapor Deposition (CVD), Solution Gelation (Sol-Gel), dan Pulse Laser Deposition (PLD). Metoda-metoda tersebut memerlukan peralatan-peralatan yang cukup komplek (Effendi dan Bilalodin, 2012). Sebagai alternatifnya, digunakan metoda Liquid Phase Deposition (LPD) untuk penumbuhan lapisan $\mathrm{TiO}_{2}$. Metoda ini sangat mudah, tidak menggunakan peralatan yang canggih serta dapat dipantau dan dikontrol selama proses penumbuhan lapisan (Gutiérrez, dkk., 2007).

\section{METODE PENELITIAN}

Bahan yang digunakan dalam penumbuhan lapisan $\mathrm{TiO}_{2}-\mathrm{Cu}$ yaitu Ammonium hexafluorotitanate $\left(\left(\mathrm{NH}_{4}\right)_{2} \mathrm{TiF}_{6}\right)$ yang diproduksi dari Sigma-Aldrich digunakan sebagai bahan dasar (prekusor) $\mathrm{TiO}_{2}$, Hexamethylen tetramine (HMT) berfungsi sebagai surfaktan, Copper (II) Nitrate hydrate $\left(\mathrm{Cu}\left(\mathrm{NO}_{3}\right)_{2} \cdot \mathrm{xH}_{2} \mathrm{O}\right)$ berfungsi sebagai dopan juga diproduksi dari Sigma-Aldrich. Lapisan $\mathrm{TiO}_{2}-\mathrm{Cu}$ disintesis diatas substrat ITO.

Substrat ITO dibersihkan melalui prosedur pembersihan standar dengan menggunakan larutan aceton dan kemudian direndam di dalam larutan etanol. Selama proses pembersihan substrat ITO diiringi dengan menggunakan ultrasonic cleaner selama 15 menit. Substrat yang dibersihkan kemudian direndam secara vertikal dalam larutan campuran yang terdiri dari $5 \mathrm{ml}$ Ammonium hexafluorotitanate $\left(\left(\mathrm{NH}_{4}\right)_{2} \mathrm{TiF}_{6}\right)$ dengan konsentrasi 0,5 M; $1 \mathrm{ml}$ Copper (II) Nitrate hydrate dengan konsentrasi 0,05 M; dan $1 \mathrm{ml}$ Hexamethylen tetramine (HMT) dengan konsentrasi 0,5 M.

Variasi lama penumbuhan lapisan $\mathrm{TiO}_{2}-\mathrm{Cu}$ yaitu 3, 5, 7 dan 10 jam dengan suhu penumbuhan $90{ }^{\circ} \mathrm{C}$. Lapisan $\mathrm{TiO}_{2}-\mathrm{Cu}$ yang terbentuk kemudian diannealing pada suhu $400{ }^{\circ} \mathrm{C}$ selama 1,5 jam. Selanjutnya lapisan $\mathrm{TiO}_{2}-\mathrm{Cu}$ dikarakterisasi menggunakan Spektrometri Ultraviolet-Visible (UV-Vis) merk HITACHI U-3900H untuk menentukan energi gap melalui spektra difusi reflektansi. Penentuan energi gap lapisan $\mathrm{TiO}_{2}-\mathrm{Cu}$ dengan cara menarik ekstrapolasi pada daerah linier dari grafik hubungan $h v$ pada sumbu $\mathrm{x}$ dan $(\alpha h v)^{2}$ pada sumbu y hingga memotong sumbu energi (Chigane, dkk., 2011). Perhitungan nilai $h v$ dan $(\alpha h v)^{2}$ ditentukan dengan menggunakan persaman 1.

$$
(\alpha h v)=C(h v-E g)^{1 / 2}
$$

Dimana $C$ adalah konstanta, $h v$ adalah energi foton dan $E g$ adalah energi gap.

\section{HASIL DAN DISKUSI}

Gambaran pengolahan data hasil penelitian yang diperoleh dalam menentukan energi gap ditampilkan pada Gambar 1 sedangkan data nilai energi gap $\mathrm{TiO}_{2}-\mathrm{Cu}$ dengan variasi lama penumbuhan ditunjukkan pada Tabel 1 . 


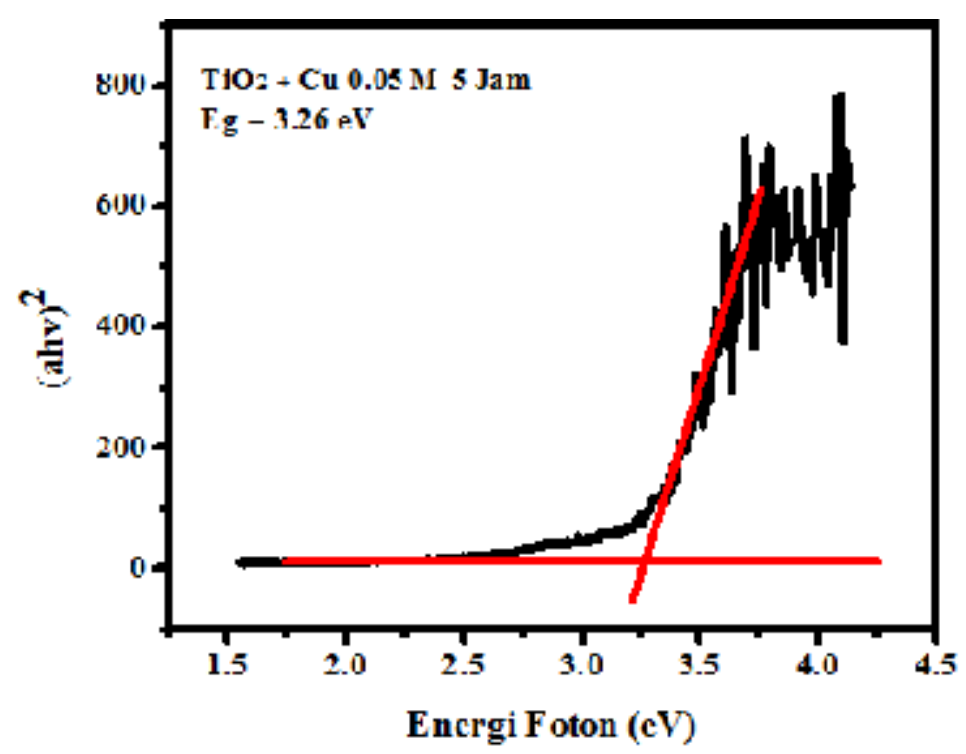

Gambar 1. Energi Gap $\mathrm{TiO}_{2}$ Didoping $\mathrm{Cu}$ 0,05 M dengan Lama Penumbuhan 5 Jam

Tabel 1. Energi Gap $\mathrm{TiO}_{2}$ Didoping $\mathrm{Cu}$ dengan Konsentrasi 0,05 M

\begin{tabular}{cc}
\hline Waktu Penumbuhan & Energi Gap \\
\hline 3 jam & $3,29 \mathrm{eV}$ \\
5 jam & $3,26 \mathrm{eV}$ \\
$7 \mathrm{jam}$ & $3,30 \mathrm{eV}$ \\
$10 \mathrm{jam}$ & $3,28 \mathrm{eV}$ \\
\hline
\end{tabular}

Dari hasil energi gap $\mathrm{TiO}_{2}$ tanpa doping yang diperoleh yaitu $3,46 \mathrm{eV}$ dibandingkan dengan hasil energi gap pada Tabel 1, menunjukkan bahwa terjadi penurunan energi gap $\mathrm{TiO}_{2}$. Ini membuktikan bahwa adanya penambahan doping $\mathrm{Cu}$ ke dalam $\mathrm{TiO}_{2}$ dapat menurunkan energi gap. Penurunan energi gap ini disebabkan adanya pembentukan tingkat energi baru dalam $\mathrm{TiO}_{2}$ yang diakibatkan oleh adanya doping logam (Yadav, dkk., 2014). Pembentukan tingkat energi baru ini berada antara pita valensi dan pita konduksi.

Perhitungan energi gap dilakukan pada lapisan $\mathrm{TiO}_{2}-\mathrm{Cu}$ dengan lama penumbuhan yang bervariasi (Tabel 1). Terlihat pada Tabel 1 bahwa hasil energi gap yang masing-masing lapisan dengan lama penumbuhan menunjukkan tidak adanya hubungan linieritas antara energi gap dengan lama penumbuhan lapisan. Nilai energi gap yang diperoleh dengan variasi lama penumbuhan lapisan $\mathrm{TiO}_{2}-\mathrm{Cu}$ berkisar antara $3,26-3,30 \mathrm{eV}$.

\section{KESIMPULAN}

Telah berhasil dibuat lapisan $\mathrm{TiO}_{2}$ didoping $\mathrm{Cu}$ dengan variasi lama penumbuhan menggunakan metoda Liquid Phase Deposition (LPD). Dari hasil penelitian yang telah dilakukan, disimpulkan bahwa adanya penurunan energi gap ketika lapisan $\mathrm{TiO}_{2}$ didoping dengan $\mathrm{Cu}$. Hasil energi gap $\mathrm{TiO}_{2}$ didoping $\mathrm{Cu}$ dengan variasi lama diperoleh sekitar 3,26 - 3,30 eV. Hasil energi gap yang diperoleh menunjukkan tidak adanya hubungan linearitas antara energi gap dan lama penumbuhan lapisan $\mathrm{TiO}_{2}-\mathrm{Cu}$. 


\section{UCAPAN TERIMAKASIH}

Penulis mengucapkan terimakasih kepada:

1. Institute Of Microengineering and Nanoelectronics (IMEN), Universiti Kebangsaan Malaysia yang telah bersedia menerima penulis untuk dapat melakukan penelitian.

2. Bakrie Center Foundation yang telah memberikan bantuan beasiswa Bakrie Graduate Fellowship kepada penulis.

\section{DAFTAR PUSTAKA}

1. Chigane, M., Watanabe, M., \& Shinagawa, T. (2011). Preparation of Hollow Titanium Dioxide Shell Thin Films from Aqueous Solution of Ti-Lactate Complex for DyeSensitized Solar Cells. INTECH Open Access Publisher.

2. Effendi, M. dan Bilalodin. (2012). Analisis Sifat Optik Lapisan Tipis $\mathrm{TiO}_{2}$ Doping Nitrogen yang Disiapkan dengan Metode Spin Coating. Prosiding Pertemuan Ilmiah XXVI HFI Jateng \& DIY.

3. Gutiérrez-Tauste, D., Domènech, X., Casañ-Pastor, N., \& Ayllón, J. A. (2007). Characterization of Methylene Blue/ $\mathrm{TiO}_{2}$ Hybrid Thin Films Prepared by The Liquid Phase Deposition (LPD) Method: Application for Fabrication Of Light-Activated Colorimetric Oxygen Indicators. Journal of Photochemistry and Photobiology A: Chemistry, 187(1), 45-52.

4. Nurmawarti, I., Abdullah, M., dan Khairurrijal. (2009). Distribusi Celah Pita Energi Titania Kotor. Jurnal Nanosains dan Nanoteknologi,. ISSN 1979-0880, hal 38-42.

5. Li, X. D., Zhang, D. W., Chen, S., Wang, Z. A., Sun, Z., Yin, X. J., and Huang, S. M. (2010). Enhancing efficiency of dye-sensitized solar cells by combining use of $\mathrm{TiO}_{2}$ nanotubes and nanoparticles. Materials Chemistry and Physics, 124(1), 179-183.

6. Roose, B., Pathak, S., and Steiner, U. (2015). Doping of $\mathrm{TiO}_{2}$ for Sensitized Solar Cells. Chemical Society Reviews, Vol 44, 8326-8349.

7. Saad, S. K. M., Umar, A. A., Nguyen, H. Q., Dee, C. F., Salleh, M. M., and Oyama, M. (2014). Porous (001)-faceted $\mathrm{Zn}$-doped anatase $\mathrm{TiO}_{2}$ nanowalls and their heterogeneous photocatalytic characterization. RSC Advances, 4(100), 57054-57063.

8. Saehana, S., Darsikin., Prasetyowati, R., Hidayat, M, I., Abdullah, M., dan Khairurrijal. (2010). Sel Surya Berbasis Material Nanokomposit $\mathrm{TiO}_{2}$. Prosiding Pertemuan Ilmiah.

9. Yadav, H. M., Otari, S. V., Koli, V. B., Mali, S. S., Hong, C. K., Pawar, S. H., \& Delekar, S. D. (2014). Preparation and Characterization of Copper-Doped Anatase $\mathrm{TiO}_{2}$ Nanoparticles with Visible Light Photocatalytic Antibacterial Activity. Journal of Photochemistry and Photobiology A: Chemistry, 280, 32-38. 